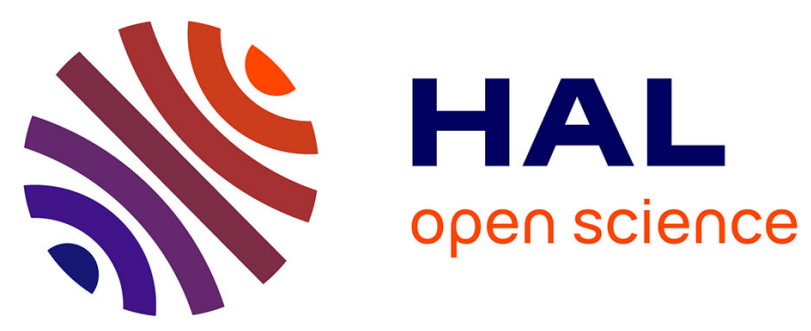

\title{
Presence of non-pathological low grade inflammation reduces physical performances in elderlies without altering protein metabolism response to food intake
}

Caroline Buffière, Isabelle Savary-Auzeloux, Martine Duclos, Carole Migné, Serge Hercberg, Noël Cano, Didier Remond, Dominique Dardevet

\section{To cite this version:}

Caroline Buffière, Isabelle Savary-Auzeloux, Martine Duclos, Carole Migné, Serge Hercberg, et al.. Presence of non-pathological low grade inflammation reduces physical performances in elderlies without altering protein metabolism response to food intake. 34th Congress of the European Society of Clinical Nutrition and Metabolism (ESPEN), Sep 2012, Barcelone, France. , Clinical Nutrition Supplements, 7 (1), 2012, 10.1016/S1744-1161(12)70566-5 . hal-02744746

\author{
HAL Id: hal-02744746 \\ https://hal.inrae.fr/hal-02744746
}

Submitted on 3 Jun 2020

HAL is a multi-disciplinary open access archive for the deposit and dissemination of scientific research documents, whether they are published or not. The documents may come from teaching and research institutions in France or abroad, or from public or private research centers.
L'archive ouverte pluridisciplinaire HAL, est destinée au dépôt et à la diffusion de documents scientifiques de niveau recherche, publiés ou non, émanant des établissements d'enseignement et de recherche français ou étrangers, des laboratoires publics ou privés. 
tolerance and diabetes. Whey protein is particularly insulinogenic. The aim of this trial was to test 3 processed whey proteins (Intact vs Hydrolyzed vs Microgel) in a meal on insulin, glucagon and glycemic responses in men.

Methods: In a cross-over, randomized, double blinded trial, 23 healthy adult men ingested 4 high-protein meals (30\% energy) separated by a week. The proteins were the whey protein as isolate (WPI), hydrolysate (WPH) and microgel (WPM) and as reference, casein (CAS). Blood was collected after ingestion. Statistical pair-wise comparisons were used.

Results: The areas under the curve (AUCs) of glycemia were similar between meals. The insulinogenic indexes were $3.7 \pm 0.5,2.6 \pm 0.4,2.3 \pm 0.2$ and $1.9 \pm 0.2($ Mean \pm SE) after WPH, WPI, CAS and WPM meal ingestion, respectively $(\mathrm{P}<0.04$ between WPH and other proteins, otherwise NS). Insulin peak concentration (Cmax) after WPM meal ( $\left.573 \pm 47 \mathrm{pmol} \cdot \mathrm{L}^{-1}\right)$ was similar than after CAS meal and lower than after WPH and WPI meals (745-780 pmol. $\left.L^{-1}, P<0.004\right)$. Glucagonemia of WPM and CAS were lower than that of WPH and WPI $(P<0.05)$. WPH and WPI induced highest GLP-1. Amino acidemia (AA) after WPH and WPI meals was higher than after CAS meal. WPM meal induced equaled AA Cmax than WPI meal but delayed by $30 \mathrm{~min}$. Total AA, essential AA, branchedchain AA and leucine showed lowest values $30 \mathrm{~min}$ and highest values 120 min after WPM meal intake.

Conclusion: WPM meal reduces acutely insulinemia and glucagonemia compared to WPH and WPI meals, while showing same glycemia in healthy men. WPM meal shows a delayed AA peak, which might explain the reduced hormonal responses. Forming microgels confers new biological functionalities to the whey protein with potential long-term health benefits.

Disclosure of Interest: None Declared.

\section{PP227-MON Outstanding abstract PRESENCE OF NON-PATHOLOGICAL LOW GRADE INFLAMMATION REDUCES PHYSICAL PERFORMANCES IN ELDERLIES WITHOUT ALTERING PROTEIN METABOLISM RESPONSE TO FOOD INTAKE}

C. Buffière ${ }^{1}$, I. Savary-Auzeloux ${ }^{1}$, M. Duclos ${ }^{2}$, C. Migné ${ }^{1}$, S. Hercberg ${ }^{3}, \mathrm{~N}$. Cano $^{2}$, D. Rémond ${ }^{1}$, D. Dardevet ${ }^{1}$. ${ }^{1}$ Nutrition Humaine, INRA, CEYRAT, ${ }^{2}$ Nutrition Humaine, CHRU, Clermont-Ferrand, ${ }^{3}$ Unité de Recherche en Epidémiologie Nutritionnelle, Inra/CNAM/Université Paris, Paris, France

Rationale: Increased CRP levels have been correlated to sarcopenia in elderly people. On the other hand, in rodents, low grade inflammation (LGI) has been shown to be responsible of an anabolic resistance of muscle protein metabolism to food intake. However, it is not known if the presence of a chronic LGI without pathologies in aged volunteers alters protein metabolism response at the postprandial state (PP) and results in decreased fat free mass and muscle function.

Methods: Elderly healthy male volunteers (69 yo) presenting no (CRP $=0.7 \pm 0.1 \mathrm{mg} / \mathrm{ml}$ ) or a chronic $L G I$ $(C R P=2.8 \pm 0.3)$ for 8 weeks were infused with ${ }^{13}$ Cleucine at the post absorptive state (PA) and at the PP state following ingestion of sequential test meals. Whole body protein and albumin synthesis, proteolysis and amino acid splanchnic extraction were measured as well as muscle power, strength and physical performances (VO2 max).

Results: No difference in BMI, total fat and fat free mass was recorded. Whole body leucine flux, protein synthesis (PA: $1.72 \pm 0.21$ vs $1.73 \pm 0.18$; PP: $1.56 \pm 0.18$ vs $1.66 \pm 0.17$ in $\mathrm{T}$ and LGI, respectively) proteolysis, leucine splanchnic extraction (19\% vs $17 \%$ ) or albumin synthesis were not altered by the presence of LGI at both the PA or the PP states. However, trail of strength showed a decrease of total power developed, VO2 max and the duration of the test by $20 \%, 23 \%$ and $25 \%$ respectively. Leg muscle strength was decreased by $24 \%(P<0.1)$.

Conclusion: In healthy elderly volunteers, the presence of chronic LGI was associated with decreased physical performances without changes in total fat free mass or alteration of whole body protein metabolism in response to food intake. It may be hypothesized that higher inflammatory states are required to alter significantly protein metabolism and muscle mass but are nevertheless sufficient to decrease physical performances.

Disclosure of Interest: None Declared.

\section{PP228-MON \\ Outstanding abstract NUTRITION SUPPORT DECREASES RISK OF PROTEIN CATABOLISM IN PATIENTS UNDERGOING BONE MARROW TRANSPLANTATION}

V. Matushevskaya ${ }^{1}$, D. Fedorenko ${ }^{1}$, V. Melnichenko ${ }^{1}$, G. Tikhova ${ }^{2}{ }^{1}$ Pirogov National Medical Surgical Center, ${ }^{2}$ Peoples Friendship University of Russia Faculty of Medical Retraining, Moscow, Russian Federation

Rationale: Establishing objective patient-focused goals of nutritional therapy is worthwhile to provide adequate and easy-to-assess nutritional support (NS). We aimed to test effect of $100 \%$ covering of total energy expenditure (TEE) on severity of catabolism in bone marrow transplantation (BMT) patients at different time-points of treatment before and after BMT.

Methods: Autoimmune $(n=129)$ and oncohematologic $(n=82)$ patients underwent BMT: mean age $34.2 \pm 11.4$ years, male/female $96 / 115$. Patients were examined at 4 specific time-points during treatment. The degree of catabolism was defined by estimating nitrogen balance; TEE was calculated from actual body weight according to Harris-Benedict equation including factors of correction. Results: In autoimmune diseases group the rate of noncatabolic patients was significantly higher at energy intake equaled $100 \%$ TEE or more comparing with those who received less than $100 \%$ TEE: before $B M T R R=2.82$ $(1.71 ; 4.64)$, after $B M T D+7 R R=8.03(0.87 ; 74.75)$ and $D+14 R R=2.06(0.83 ; 5.13)$. But at BMT time-point no association between rate of catabolism and energy intake in percents of TEE was found: $R R=1.38(0.32 ; 5.96)$. The same relationship was found in oncohematologic patients group: before $B M T R R=2.17(1.32 ; 3.86)$, after $B M T D+7$ $\mathrm{RR}=7.38(2.45 ; 22.21)$ and $\mathrm{D}+14 \mathrm{RR}=7.67(2.77 ; 21.23)$, but at BMT all patients were severely catabolic.

Conclusion: At BMT time-point NS doesn't control severity of catabolism in BMT patients as successfully as it does at the other phases of treatment. Energy intake equaled $100 \%$ TEE or more substantially decreases 